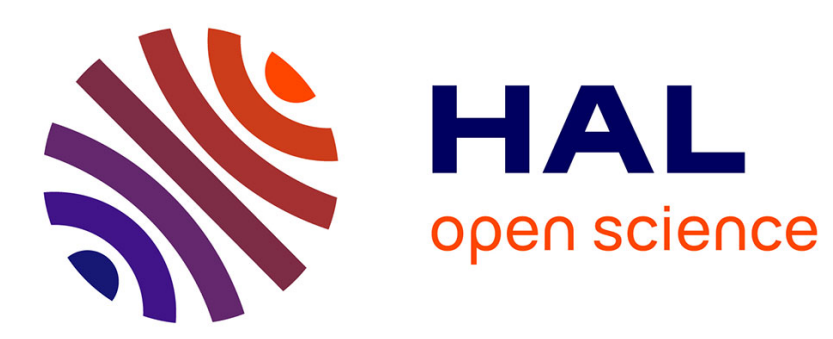

\title{
My role is my castle - The appeal of family roles after experiencing social exclusion
}

Nilüfer Aydin, Verena Graupmann, Julia Fischer, Dieter Frey, Peter Fischer

\section{To cite this version:}

Nilüfer Aydin, Verena Graupmann, Julia Fischer, Dieter Frey, Peter Fischer. My role is my castle - The appeal of family roles after experiencing social exclusion. Journal of Experimental Social Psychology, 2011, 10.1016/j.jesp.2011.03.020 . peer-00995257

\section{HAL Id: peer-00995257 https://hal.science/peer-00995257}

Submitted on 23 May 2014

HAL is a multi-disciplinary open access archive for the deposit and dissemination of scientific research documents, whether they are published or not. The documents may come from teaching and research institutions in France or abroad, or from public or private research centers.
L'archive ouverte pluridisciplinaire HAL, est destinée au dépôt et à la diffusion de documents scientifiques de niveau recherche, publiés ou non, émanant des établissements d'enseignement et de recherche français ou étrangers, des laboratoires publics ou privés. 


\section{Accepted Manuscript}

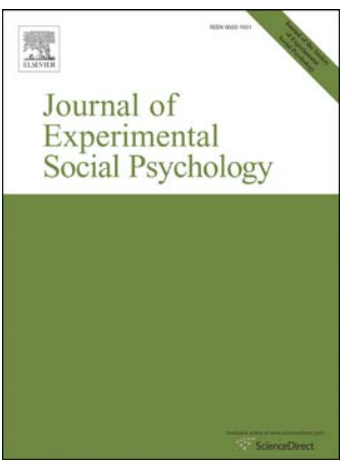

My role is my castle - The appeal of family roles after experiencing social exclusion

Nilüfer Aydin, Verena Graupmann, Julia Fischer, Dieter Frey, Peter Fischer

PII:

S0022-1031(11)00085-0

DOI:

doi: 10.1016/j.jesp.2011.03.020

Reference:

YJESP 2651

To appear in: Journal of Experimental Social Psychology

Received date: $\quad 26$ November 2010

Revised date: $\quad 10$ March 2011

Accepted date: $\quad 24$ March 2011

Please cite this article as: Aydin, N., Graupmann, V., Fischer, J., Frey, D. \& Fischer, P., My role is my castle - The appeal of family roles after experiencing social exclusion, Journal of Experimental Social Psychology (2011), doi: 10.1016/j.jesp.2011.03.020

This is a PDF file of an unedited manuscript that has been accepted for publication. As a service to our customers we are providing this early version of the manuscript. The manuscript will undergo copyediting, typesetting, and review of the resulting proof before it is published in its final form. Please note that during the production process errors may be discovered which could affect the content, and all legal disclaimers that apply to the journal pertain. 


\section{Running Head: SOCIAL EXCLUSION AND APPEAL OF FAMILY ROLES}

\section{My role is my castle -}

The appeal of family roles after experiencing social exclusion

*Nilüfer Aydin,

* Verena Graupmann, *Julia Fischer, *Dieter Frey \& **Peter Fischer

*University of Munich (LMU), Germany

**University of Graz, Austria

Address for Correspondence:

Dr. Nilüfer Aydin

Department of Social Psychology

Ludwig-Maximilians-University

Leopoldstr.13

80802 Munich, Germany

E-Mail: Aydin@psy.lmu.de

Phone: +49 - (0)89-2180-4875

(Word count: 4.248) 


\begin{abstract}
The present research investigated whether perceived social exclusion would lead women to embrace the social group of the family (and its traditional gender roles). In two studies, it was found that in comparison to a social inclusion manipulation, a social exclusion manipulation caused women to report significantly more positive inclinations towards traditional, gendered work allocations (Study 1 and 2). Moreover, seeking meaning in life mediated the relationship between social exclusion and the perceived attractiveness of the roles of mother and housewife (Study 2). In a third study, adherence to family-related concepts was examined in both socially excluded and included men, but no difference was found between the two groups. It thus appears that social exclusion does not enhance the attractiveness of familial relationships for men. The theoretical and practical implications of these findings are discussed.
\end{abstract}

Key words: social exclusion, gender, coping, meaningful existence 


\section{My role is my castle -}

\section{The appeal of family roles after experiencing social exclusion}

Forms of ostracism are omnipresent, cross-cultural social phenomena that can be described as fundamental sources of threat to an individual's physical and psychological wellbeing (e.g. Baumeister \& Tice, 1990; Leary, 1990). Given that forming and maintaining social bonds is one of the most important human motivations (Baumeister \& Leary, 1997; Maslow, 1968), being socially excluded has tremendously painful and stressful outcomes for individuals, and can create feelings of emotional distress and uncertainty (Eisenberger, Lieberman \& Williams, 2003; Zadro, Williams, \& Richardson, 2004). A question consequently rises regarding how people cope with the negative affect caused by social exclusion. One possible strategy for overcoming such adverse outcomes is to turn to the traditional social roles of the family, which can provide the individual with secure attachments. Research has consistently shown that holding traditional values is positively associated with perceived security and emotional certainty (e.g. Jost et al., 2007). Thus, could the fixed and secure social bonds implicit in traditional social roles provide a buffer against experienced social exclusion?

\section{Coping with social exclusion}

Previous research has repeatedly shown that social exclusion elicits pro-social responses in individuals, as a way of facilitating reconnection and affiliation with others (Maner, DeWall, Baumeister \& Schaller, 2007; Gardner, Picket \& Brewer, 2000) ${ }^{1}$ : socially excluded people have been found to demonstrate increased selective attention to signs of social acceptance (such as smiling faces; DeWall, Maner \& Rouby, 2009); improved recognition of facial expressions (Pickett, Gardner \& Knowles, 2004); enhanced sensitivity to socially relevant information (Gardner, Pickett \& Brewer, 2000) and a greater propensity to

\footnotetext{
${ }^{1}$ Research has also revealed anti-social reactions after social exclusion, such as increased aggression (Twenge, Baumeister, Tice \& Stucke, 2001) and decreased helping behaviour (Twenge et al., 2007).
} 
turn to the idea of a loving and caring personal God in order to cope with the experience of being excluded (Aydin, Fischer \& Frey, 2010).

Thus, research shows that feeling excluded can increase individuals' motivations to reconnect with others and detect potential sources of affiliation. It has also provided evidence that the specific social group of the family functions as a major source of intimate and durable relationships (see Baumeister, 1991). In the present research, we subsequently argue that turning to the family (with its traditional role allocations) may function as an ideal strategy for socially excluded people to (re-)gain inclusion. Prioritising family might offer adherence to traditional social arrangements, fulfil affiliation motives and provide satisfaction through perceptions of living a meaningful existence.

\section{Family as an anxiety buffer}

The comfort-providing ability of traditional values and roles in times of crisis and uncertainty has been observed in a significant body of research. For example, it has been found that perceptions of threat and danger are associated with a preference for ideas that emphasize stability and traditional social arrangements (Jost, Glaser, Kruglanski \& Sulloway, 2003; Jost et al., 2007). The fact that people deal with uncertainty (in the form of existential threats) by focusing on intimate relationships and the family has been well-documented in the line of Terror Management Theory (TMT; see Pyszczynski, Greenberg \& Solomon 1997). For example, Florian, Mikulincer and Hirschberger (2002) found that both men and women reported increased romantic commitment to their partners when they were primed with mortality salience; and Kastenmüller and colleagues revealed that the threat of terrorism decreased occupational networking and increased reconnection with family and friends for both sexes (Kastenmüller et al., 2011). In addition, Fritsche and colleagues (2006) found that both anticipated and actual offspring serve as a buffer against the existential anxiety of mortality salience by satisfying attachment motivation. It can be summarized that individuals seem to search for familial affiliation in times of threat and social uncertainty. 


\section{The role of meaning after social exclusion}

Feeling socially excluded has great influence upon people's perceptions of life as being meaningful. Research has shown that socially excluded individuals experience a decline in meaningful thoughts (Twenge, Catanese \& Baumeister, 2003); perceive themselves as being non-existent in the situation of social exclusion (Zadro, Williams \& Richardson, 2004); and indicate a global decrease in their perceptions of life as meaningful (Zadro, Boland \& Richardson, 2006; Stillmann et al., 2009). Furthermore, Stillman and colleagues (2009) found that both loneliness and rejection predicted lower levels of perceived meaningfulness in life, with rejected people observing lower levels of life-meaning constituents such as efficacy, purpose, value and positive self-worth (see Study 4, Stillman et al., 2009). As meaning is primarily socially acquired through interpersonal interaction and interdependence, we hypothesized that the social unit of the family would gain even more significance when one's need to live a meaningful existence has been thwarted by social exclusion.

The aim of the present research was thus to examine whether the conception of the family as a promising source of affiliation and meaning serves as buffer against the adverse outcomes of social exclusion. However, we also hypothesized that turning to the family would occur in socially excluded women rather than socially excluded men. Empirical findings show that women generally satisfy their need to belong by forming intimate (familial) bonds, whereas men satisfy their belonging needs by emphasizing status and power structures outside of the domestic circle (see Baumeister \& Sommer, 1997; Lerner \& Mikula, 1994). Therefore, women may be particularly likely to perceive family-related cognitions as a source of intimate security and affiliation when facing forms of ostracism.

\section{The current research}

Given the association between turning to the family and threats to security and belonging; the present research investigated whether social exclusion would lead to increased attraction to traditional gender roles and family-related concepts, particularly for women. We 
hypothesized that women who experienced significant social exclusion would indicate higher levels of desire for the traditional roles of mother and housewife (Study 1 and 2) when compared to women who felt socially included, and that this effect might be mediated by needs for belonging and/or meaningful existence (Study 2). We also hypothesized that this effect would not be replicated in a male sample, assuming that socially excluded men would not indicate higher attraction to domestic-related concepts when compared to socially included men (Study 3).

\section{Study 1}

\section{Participants and design}

Fifty-eight female undergraduates (age: $M=24.29 ; S D=3.73$, ranging from 20 to 45 years old) from the University of Munich (LMU) participated in exchange for course credit. Study 1 had a single-factor, between-subjects design with social exclusion (social exclusion; social inclusion) as the independent variable. Participants were randomly assigned to one of the two conditions.

\section{Method}

\section{Materials and procedure}

In Study 1, we used a scenario manipulation, during which a group task situation was described. Participants were randomly assigned to one of the two experimental conditions: social exclusion or social inclusion. All participants were then asked to read a short paragraph about a situation at the University, and instructed to imagine themselves as a member of a student trio that was working collaboratively on a presentation for a seminar. Aim of this manipulation was to generate feelings of social exclusion vs. social inclusion in participants. Participants in the social exclusion condition were told that their fellow students showed no interest in the participants' own ideas and suggestions. Furthermore, the other students did not communicate with them, instead behaving ignorantly and leaving them feeling unpleasant. In contrast, participants in the social inclusion condition were told that they were strongly 
accepted by their fellow students, who were extremely interested in their ideas and highly motivated to communicate with them.

Afterwards, a manipulation check was conducted in order to test whether participants in the social exclusion condition felt more socially excluded than those in the social inclusion condition. Participants were asked to respond to the items "How excluded did you feel in the situation described?" and "How uncomfortable did you feel in the situation described?" on a scale from 1 (absolutely not) to 10 (very much). A positive correlation was found between both items; $r(57)=.94, p<.001$. They were subsequently collapsed into one scale.

Upon completing the manipulation check, ratings of positive and negative affect were obtained via PANAS (Positive and Negative Affect Scales; Watson, Clark, \& Tellegen, 1988; $\alpha=.85$ for positive affect and $\alpha=.86$ for negative affect).

Next, participants were asked to read a short newspaper article, which contained a report discussing a recent change of attitudes in female university graduates regarding the role women should play in society. The article was based on a sociological study that had (allegedly) discovered that many female German university graduates supported the idea of a return to traditional gender role allocations, implying that women should stay at home and accept their familial obligations. Furthermore, it was reported that many well-educated women had opted against a professional career and instead preferred to take the positions of mother and housewife.

\section{Dependent measures}

To assess the desire for and perceived attractiveness of the roles of mother and housewife, participants were asked to indicate their personal attitude toward gender role allocation by responding to the following four items (on a scale from 1 [disagree very strongly] to 10 [agree very strongly]): "I think the reported trend is positive"; "I think it makes sense that women are now looking more for happiness in their families than in the business world"; "Real happiness can only be found in the role of a mother and wife" and 
"The time where women could only define themselves through their family is over" (reverse coded). The four item scale showed high internal consistency $(\alpha=.81)$. After completing the questionnaire, participants were thanked for their contributions and thoroughly debriefed regarding the study's aim.

\section{Results and Discussion}

Manipulation check. An independent t-test revealed that participants in the social exclusion condition reported significantly higher levels of feeling socially excluded and uncomfortable $(M=7.51, S D=2.21)$ than participants in the social inclusion condition $(M=$ $2.18, S D=1.55), t(52.00)=10.60, p<.001$. The manipulation of social exclusion had no effect on positive or negative emotions, all $p s>.20 .^{2}$

Attraction to motherhood and family. An independent t-test revealed that socially excluded women reported higher levels of acceptance of conventional gender work allocation (indicating motherhood and the role of housewife) for well-educated females $(M=3.72, S D=$ 1.78) than women who felt socially accepted $(M=2.87, S D=1.35), t(56)=2.03, p=.047, d$ $=0.53$.

In summary, Study 1 provided initial empirical evidence that social exclusion indeed increases both the desire for and attractiveness of the conventional roles of mother and housewife in certain young women. Socially excluded female participants showed higher levels of sympathy for a traditional perspective on gender work allocation compared to female participants who felt socially accepted.

\section{Study 2}

The aim of Study 2 was (1) to replicate the findings found in Study 1 with a different manipulation of social exclusion (using an autobiographical essay task; see Gardner et al., 2000); (2) to measure the dependent variable implicitly by assessing the accessibility of

\footnotetext{
${ }^{2}$ This result is consistent with prior findings indicating null effects for emotion after social exclusion, implying emotional numbness after episodes of social exclusion (e.g. Twenge et al., 2001; DeWall \& Baumeister, 2006; Baumeister, DeWall \& Vohs, 2009).
} 
family-related thoughts following social exclusion; and (3) to examine needs for belonging and meaningful existence as possible mediating variables.

\section{Participants and design}

Of fifty-eight female undergraduates (LMU of Munich) who completed the study, one was dropped from the analysis for not fulfilling the essay writing task. Therefore, the data from 57 female participants was used (age: $M=23.66, S D=2.47$, ranging from 18 to 30 years old) in Study 2. The study consisted of a one-factorial design with two independent conditions: social exclusion and social inclusion. Participants were randomly assigned to one of the two conditions.

\section{Method}

\section{Materials and procedure}

In Study 2, participants were asked to write a short autobiographical essay. Participants in the social exclusion condition were asked to consider a life event during which they had experienced severe social exclusion but had not known its reason, and to write a short essay about it. In contrast, individuals in the social inclusion condition were asked to think about a life event in which they had felt completely accepted, and wrote a short essay about that.

Next, a manipulation check identical to the one in Study 1 was conducted. Both items correlated positively with each other, $r(53)=.78, p<.001$, and were subsequently collapsed into one scale.

Afterwards, participants reported their positive and negative affect via PANAS ( $\alpha$ $=.87$ for positive affect; $\alpha=.84$ for negative affect).

In the next step, threats to needs for belonging and meaningful existence were assessed by two items, which were responded to on a 10-point Likert scale ranging from 1 (not at all) to 10 (very much). The items were "I have a strong desire to belong to a group" and "I am searching for meaning in my life". 


\section{Dependent measures}

A word completion task was conducted to detect thoughts related to motherhood and family. Participants were given a list of six words with missing letters, and told that each of the presented words had several correct completion possibilities. Participants were then tasked with completing the word fragments as quickly as possible. Each fragment could be completed either to words related to motherhood and family, or to neutral words. Fragments could be completed to mother ("Mutter") or alternatively to feed ("Futter"); marriage ("Ehe") or owl (“Uhu”); son (“Sohn”) or poppy (“Mohn”); love (“Liebe”) or thieves (“Diebe”); home (“Heim”) or rhyme (“Reim”), and children (“Kinder") or cows (“Rinder"). ${ }^{3}$ The number of word fragments completed to family-related words was turned into an accessibility score. After completing the questionnaire, participants were thanked for their contributions and thoroughly debriefed regarding the aim of the study.

\section{Results and Discussion}

Manipulation check. The manipulation of social exclusion proved successful, with participants in the social exclusion condition reporting significantly higher levels of felt social exclusion and situational discomfort $(M=7.22, S D=1.81)$ than participants in the social inclusion condition $(M=1.84 ; S D=1.74), t(51)=10.97, p<.001$. As in Study 1 , no effect of social exclusion was found on positive or negative emotions, all $p \mathrm{~s}>.10$.

Attraction to motherhood and family. Independent t-tests revealed that socially excluded women completed more word fragments to words related to family and motherhood $(M=2.86, S D=1.80)$ than women who felt socially accepted $(M=1.77, S D=1.31), t(54)=$ $2.55, p=.014, d=0.70$.

Mediating variables. Independent t-tests revealed a significant effect of social exclusion on searching for meaning in life, $t(53)=2.51, p=.015, d=0.69$, indicating that socially excluded participants demonstrated a higher need for meaning in life $(M=7.75, S D=$

\footnotetext{
${ }^{3}$ These word fragments could have also been completed as neutral words other than those described above; e.g. cutter ("Kutter") instead of mother ("Mutter").
} 
1.78) than socially included participants $(M=6.25, S D=2.42)$. No significant effect was observed for the need to belong $(p>.18)$.

Furthermore, a significant positive correlation was found between need for meaningful existence and number of family-related words, $r(55)=.42, p=.002$. A bootstrapping analysis based on 5,000 bootstraps was subsequently executed, in order to examine whether the need for meaning in life mediated the found effect (Preacher \& Hayes, 2004).

Results showed a significant direct effect of social exclusion on the number of familyrelated words, $t=-2.49, p=.015$, which was reduced to non-significance, $t=1.62, p=.11$, when controlling for the mediator variable 'search for meaning'. In addition, the true indirect effect was estimated to lie between -.8590 and -.0385 with a $95 \%$ confidence interval. Because zero is not in this interval, one can conclude that the real indirect effect became significant at $p<.05$ (two-tailed). Thus, it appears that searching for meaning in life mediates the effect of social exclusion on the attractiveness of the roles of mother and housewife.

To summarize, Study 2 replicated the effect of social exclusion on attraction to family on a more implicit level; additionally revealing that it is searching for meaning in life (rather than the need to belong) that mediates the effect of social exclusion on attraction to traditional domestic roles.

\section{Study 3}

In order to examine whether socially excluded men would also evince increased accessibility of family-related concepts (in comparison to socially included men), we replicated Study 2 with a male sample in Study 3. Research has shown that men prefer to satisfy their belonging needs by pursuing (broader) interpersonal relationships outside the familial domain (Baumeister \& Sommer, 1997). We thus hypothesized that compared to socially included women, socially excluded men would not subsequently demonstrate heightened responses to the family unit.

\section{Participants and design}


Thirty-nine male undergraduates (ages: $M=22.00, S D=2.95$; ranging from 19 to 32 years) from the University of Munich (LMU of Munich) participated in Study 3 in exchange for course credit. The study consisted of a one-factorial design with two independent conditions: social exclusion and social inclusion, with participants being randomly assigned to one of the two conditions.

\section{Method}

\section{Materials and procedure}

The materials and procedure in Study 3 were identical to the ones used in Study 2. Participants in the social exclusion condition were asked to write a short autobiographical essay about a life event in which they had felt completely excluded. In contrast, individuals in the social inclusion condition were asked to think about a life event in which they had felt completely accepted, and wrote a short essay about that.

Afterwards, a manipulation check identical to the ones used in Study 1 and Study 2 was conducted. Both items correlated positively with each other, $r(34)=.68, p<.001$, and were subsequently collapsed into one scale.

Afterwards, participants reported their positive and negative emotions via PANAS $(\alpha$ $=.85$ for positive affect; $\alpha=.78$ for negative affect). Threats to needs for belonging and meaningful existence were also assessed, using the same two items employed in Study 2.

\section{Dependent measures}

As in Study 2, a word completion task was conducted to test the effect of social exclusion on the cognitive accessibility of family-relevant thoughts. The number of word fragments completed to family-related words was once again turned into an accessibility score. After completing the questionnaire, participants were thanked for their contributions and debriefed regarding the aim of the study.

\section{Results and Discussion}


Manipulation check. An independent t-test showed that socially excluded participants reported significantly higher levels of felt social exclusion and situational discomfort $(M=$ $6.02, S D=2.31)$ than participants in the social inclusion condition $(M=1.97 ; S D=1.43)$, $t(35)=6.57, p<.001$. As in Study 1 and Study 2, no effect of social exclusion was found on positive or negative affect; all $p s>.19$.

Attraction to parenthood and family. An independent t-test revealed no difference between male participants in the social exclusion and social inclusion condition regarding completion of word fragments to words related to family concepts, $p>.75$.

Mediating variables. Independent t-tests revealed no significant effect of social exclusion on belonging needs, $p>.53$, but revealed a marginally significant effect of social exclusion on searching for meaning in life, $t(36)=1.87, p=.068$, indicating that socially excluded participants demonstrated a higher need for meaning in life $(M=7.73, S D=2.28)$ than socially included participants $(M=6.31, S D=2.38)$.

In summary, Study 3 did not replicate the findings of Studies 1 and 2. The results indicate that feeling socially excluded did not have an impact on male participants' cognitive associations with the social group of the family. This suggests that men do not tend to focus on the family more when feeling socially excluded. Furthermore, a marginal significant difference was observed between socially excluded and socially included participants regarding searching for meaning; suggesting that both men and women are affected by social exclusion in their need to live a meaningful life. Nevertheless, the results of Study 3 indicate that compared to women, men do not satisfy this motivation by focusing on family-related concepts.

\section{General Discussion}

The current studies investigated whether the threat of social exclusion would lead to more positive perceptions of the family and traditional gender roles in women and men. Study 1 demonstrated that in comparison to socially included women, women who experienced 
social exclusion reported stronger acceptance of the notion that family commitments should be prioritized in the lives of well-educated women. This effect was replicated in Study 2 using a subtler measure, showing that women who experienced social exclusion also generated more family-related words than socially included participants in a word completion task. Furthermore, searching for meaning in life mediated the relationship between social exclusion and attraction to the roles of mother and housewife. Finally, Study 3 showed that the observed effect is limited to female samples: socially excluded men did not generate more familyrelated cognitions when compared to socially included men. Although a marginal significant effect of social exclusion on seeking meaningful existence was observed in male participants, satisfying this need was not associated with the concepts of home and family (in line with Baumeister \& Sommer, 1997).

\section{Limitations}

While we are confident in our findings, we advise that they should not be generalized uncritically, because some shortcomings need to be addressed.

Firstly, our dependent variable in Study 2 and 3 (the salience of family-related cognitions) does not necessarily imply that the salience of such concepts results in favourable cognitions about them. We cannot exclude the possibility that participants may also have generated more hostile cognitions toward family, leading to a more negative perspective toward both it and its obligations. To test whether participants make beneficial associations with family-related concepts, it would have been fruitful to apply another implicit measure like the IAT (implicit association task; see Greenwald, McGhee, \& Schwartz, 1998), in order to detect the strength of implicit preferences in socially included and excluded participants toward family-related associations.

Secondly, it should be stated that there may be several obvious reasons why women might prefer to pursue a career in the home rather than outside it. It would be misleading to conclude that decisions to prioritise motherhood and marriage are directly tied to social 
exclusion experiences. It would have been beneficial to control for pre-existing preferences regarding traditional role allocation as a co-variate in our studies, in order to give due consideration to the diversity of attitudes toward traditional roles in the domestic domain.

\section{Implications and Future research}

Research has demonstrated that people who perceive their life as being less meaningful have worse mental health statuses and experience more distress; in contrast, finding meaning helps individuals to boost their mental well-being (Steger, Frazier, Oishi \& Kaler, 2006; Debats, van der Lubbe \& Wezemann, 1993). Our results showed that searching for meaning was positively linked with the acceptance and perceived attractiveness of traditional familial role allocations in women after social exclusion. Nevertheless, it remains unclear if searching for meaning by reconnecting with the social unit of the family actually decreases psychological distress caused by social exclusion, and thus promotes healthy psychological functioning in excluded women. Therefore, it is also important to address the question of how searching for meaning via familial roles associates with mental health outcomes after experiencing social exclusion. Meaning-related measures of psychological well-being (e.g. life satisfaction, happiness or optimism, see Lent, 2004; Steger et al., 2006) should thus be additionally assessed in future studies.

Our experiments have shown that even a relatively small intervention (such as our social exclusion manipulation) can lead to a tendency to attach increased value to a traditional role of members of one's social group; in this case, women prioritizing motherhood and marriage. A general caveat of previous research in social exclusion is that little empirical evidence exists regarding differences in coping responses between women and men post social exclusion. ${ }^{4}$ Our research aimed to extend previous research on coping responses to social exclusion. To our knowledge, this is the first line of research that has explicitly

\footnotetext{
${ }^{4}$ The studies of Williams \& Summer (1997) should be mentioned as an exception in the literature regarding gender differences in coping responses. The authors could reveal that socially excluded men tended to socially loaf in a working group, while socially excluded women compensated by working harder in their team.
} 
investigated the impact of social exclusion on affiliative coping responses in women. Study 3 revealed that social exclusion did not affect the salience of family-related concepts in men.

Given the paucity of studies on male coping responses after social exclusion, future research should address the research question of how men deal with incidents of social exclusion.

\section{Conclusion}

The results of the present studies contribute to the body of research examining how individuals are affected by incidents of social exclusion, doing so by extending previous research on post-exclusion affiliative coping responses and investigating the role of the family (and its traditional role allocations) as a coping resource in times of social exclusion. A challenge for future research is to investigate the specific conditions under which women and men respond to social exclusion in different ways. 


\section{References}

Aydin, N., Fischer, P., \& Frey, D. (2010). Turning to God in times of ostracism: the impact of social exclusion on religiousness. Personality and Social Psychology Bulletin, 36, 742 $-753$.

Baumeister, R. F. (1991). Meanings in Life. New York: Guilford Press.

Baumeister, R. F. \& Sommer, K. L. (1997), What do men want? Gender differences and two spheres of belongingness: Comment on Cross and Madson (1997). Psychological Bulletin, 122, $38-44$.

Baumeister, R. F., \& Tice, D. M. (1990). Anxiety and social exclusion. Journal of Social and Clinical Psychology, 9, 165-195.

Debats, D. L., van der Lubbe, P. M., \& Wezeman, F. R. A. (1993). On the psychometric properties of the Life Regard Index (LRI): A measure of meaningful life. Personality and Individual Differences, 14, 337-345.

DeWall, C. N., Maner, J. K., \& Rouby, D. A. (2009). Social exclusion and early-stage interpersonal perception: Selective attention to signs of acceptance. Journal of Personality and Social Psychology, 96, 729-741.

Eisenberger N. I., Lieberman M. D., Williams, K. D. (2003). Does rejection hurt? An fMRI study of social exclusion. Science, 302, 290-292.

Florian, V., Mikulincer, M., \& Hirschberger, G. (2002). The anxiety buffering function of close relationships: Evidence that relationship commitment acts as a terror management mechanism. Journal of Personality and Social Psychology, 82, 527-542.

Fritsche, I., Jonas, E., Fischer, P., Koranyi, N., Berger, N., \& Fleischmann, B. (2007). Mortality salience and the desire for offspring. Journal of Experimental Social Psychology, 43, 753-762.

Gardner, W., Pickett, C. L., \& Brewer, M. B. (2000). Social exclusion and selective memory: how the need to belong influences memory for social events. Personality and Social Psychology Bulletin, 26, 486-496. 
Greenwald, A. G., McGhee, D. E., \& Schwartz, J. L. K. (1998). Measuring individual differences in implicit cognition: the Implicit Association Test. Journal of Personality and Social Psychology, 74, 1464-1480.

Jost, J. T., Glaser, J., Kruglanski, A. W., \& Sulloway, F. J. (2003). Political conservatism as motivated social cognition. Psychological Bulletin, 129, 339-375.

Jost, J. T., Napier, J. L., Thorisdottir, H., Gosling, S. D., Palfai, T. P, \& Ostafin, B. (2007). Are needs to manage uncertainty and threat associated with political conservatism or ideological extremity? Personality and Social Psychology Bulletin, 33, 989 - 1007.

Kastenmüller, A., Greitemeyer, T., Aydin, N., Tattersall, A. J., Peus, C., Bussmann, P. Köppl, J., Frey, D., \& Fischer, P. (accepted). Terrorism threat and networking: Evidence that terrorism threat decreases occupational networking. Journal of Organizational Behavior.

Leary, M. R. (1990). Responses to social exclusion: Social anxiety, jealousy, loneliness, depression, and low self-esteem. Journal of Social and Clinical Psychology, 9, 221-229.

Lent, R. W. (2004). Toward a unifying theoretical and practical perspective on well-being and psychosocial adjustment. Journal of Counseling Psychology, $51,482-509$.

Lerner, M.J. \& Mikula, G. (Eds) (1994). Entitlement and the affectional bond: Justice in close relationships. New York: Plenum.

MacDonald G \& Leary M. R.( 2005). Why does social exclusion hurt? The relationship between social and physical pain. Psychological Buletin, 131, 202-223.

Maner, J. K., DeWall, C., \& Baumeister, R. F. (2007). Does social exclusion motivate interpersonal reconnection? Resolving the "porcupine problem." Journal of Personality and Social Psychology, 92, 42-55.

Maslow, A. H. (1968). Toward a psychology of being. New York: Van 


\section{Nostrand.}

Pickett, C. L., Gardner, W. L., \& Knowles, M. (2004). Getting a cue: The need to belong and enhanced sensitivity to social cues. Personality and Social Psychology Bulletin, 30, 1095-1107.

Preacher, K. J., \& Hayes, A. F. (2004). SPSS and SAS procedures for estimating indirect effects in simple mediation models. Behavior Research Methods, Instruments, \& Computers, 36, 717-731.

Pyszczynski, T., Greenberg, J., \& Solomon, S. (1997). "Why do we need what we need? A terror management perspective on the roots of human social motivation". Psychological Inquiry, 8, 1-20.

Steger, M. F., Frazier, P., Oishi, S., \& Kaler, M. (2006). The Meaning in Life Questionnaire: Assessing the presence of and search for meaning in life. Journal of Counseling Psychology, 53, 80-93.

Stillman, T. F., Baumeister, R. F., Lambert, N. M., Crescioni, A. W., DeWall, C. N., \& Fincham, F. D. (2009). Alone and without purpose: Life loses meaning following social exclusion. Journal of Experimental Social Psychology, 45, 686-694

Twenge, J. M., Baumeister, R. F., DeWall, C. N., Ciarocco, J. N., \& Bartels, J. M. (2007). Social Exclusion decreases prosocial behavior. Journal of Personality and Social Psychology, 92, $56-66$.

Twenge, J. M., Baumeister, R. F., Tice, D. M., \& Stucke, T. S. (2001). If you can't join them, beat them: effects of social exclusion on aggressive behavior. Journal of Personality and Social Psychology, 81, 1058-1069. 
Twenge, J.M., Catanese, K.R., \& Baumeister, R.F. (2003). Social exclusion and the deconstructed state: Time perception, meaninglessness, lethargy, lack of emotion, and self-awareness. Journal of Personality and Social Psychology, 85, 409-423.

Watson, D., Clark, L. A., \& Tellegen, A. (1988). Development and validation of brief measures of positive and negative affect: The PANAS Scales. Journal of Personality and Social Psychology, 54, 1063-1070.

Williams, K. D., Cheung, C. K. T., \& Choi, W. (2000). Cyberostracism: effects of being ignored over the Internet. Journal of Personality and Social Psychology, 79, 748-762.

Williams, K. D., \& Sommer, K. L. (1997). Social Ostracism by Coworkers: Does Rejection Lead to Loafing or Compensation? Personality and Social Psychology Bulletin, 23, $693-706$.

Wright, E. O., Baxter, J., \& Birkelund, E. G. (1995). The Gender Gap in the Workplace Authority - A Cross National Study. American Sociological Review, 60, 407-435.

Zadro, L., Boland, C., \& Richardson, R. (2006). How long does it last? The persistence of the effects of ostracism in the socially anxious. Journal of Experimental Social Psychology, 42, 692-697

Zadro, L., Williams, K. D., \& Richardson, R. (2004). How low can you go? Ostracism by a computer lowers belonging, control, self-esteem, and meaningful existence. Journal of Experimental Social Psychology, 40, 560-567. 